\title{
A Study on Determination and Implementation of Operation Theatre Management System in a Private Hospital, Trichy: A Six Sigma Approach
}

\author{
Vishnu V Raja', Bhooma Devi \\ ${ }^{1}$ MBA student, Sri Ramachandra College Of Management, Tamil Nadu, India \\ vishubme@gmail.com \\ ${ }^{2}$ Senior Lecturer, Sri Ramachandra College Of Management, Tamil Nadu,India \\ bhooma.ganesh@gmail.com
}

\begin{abstract}
The study aims in increasing the number of surgeries with the available resources in the operation theatre which ultimately improves the efficiency and effectiveness of operation theatre. Efficiency rate is calculated multiplying the availability of operation theatre, Number of scheduled surgeries and success rate of surgeries. This formula is commonly accepted in calculating the efficiency rate among Industrial sectors. The study covers the activities involved from patients entering pre operation theatre to transferring them to post operation theatre i.e. from admission to discharge process of operation theatre. Methodology adopted in this study is Six Sigma. The Defect per million opportunities analysis reveals that the existing sigma level is 2.6 and the existing efficiency rate is 54.5 percent. It was found that the risk priority number was high in the assessment and preparation of surgery process in which missing of pre-assessment and failure to give timely request for investigation has been identified as the failure modes. This leads to increase in average length of stay which is caused by postponement and cancellation of surgeries; this ultimately leads to reduction in productivity. The vital few items are found to be poor pre admission procedure, in adequacy in manpower, patient delay, drugs delay and slow turnaround time. Improving the efficiency by finding solutions to the root causes leading to substantial improvement in Quality of service can be achieved through Six Sigma approach which is one of the Total quality management concepts and methodologies.
\end{abstract}

\section{Keywords}

Admission, discharge, operation theatre, Surgery, Postponement, Six Sigma.

\section{ACADEMIC DISCIPLINE AND SUB-DISCIPLINES}

Hospital and Health Systems Management

\section{SUBJECT CLASSIFICATION}

Total Quality Management in Hospitals, Hospital Management

\section{Council for Innovative Research}

\author{
Peer Review Research Publishing System
}

Journal: International Journal of Management \& Information Technology

Vol. 6, No. 3

editor@cirworld.com

www.cirworld.com, member.cirworld.com 


\section{INTRODUCTION}

\section{Six Sigma:}

A number of hospitals and health systems are finding that Six Sigma is a useful tool for improving quality in the operating room. Six sigma is an integrated approach for pursuing continuous improvement of customer satisfaction as well as organization profits. Six Sigma is able to combine the available knowledge from the various functions in an organization to achieve the best possible process improvements. Organizations that implement six sigma invest in a) Quality improvement b) Cost reduction

c) Efficiency improvement.

\section{QUALITY IMPROVEMENT}

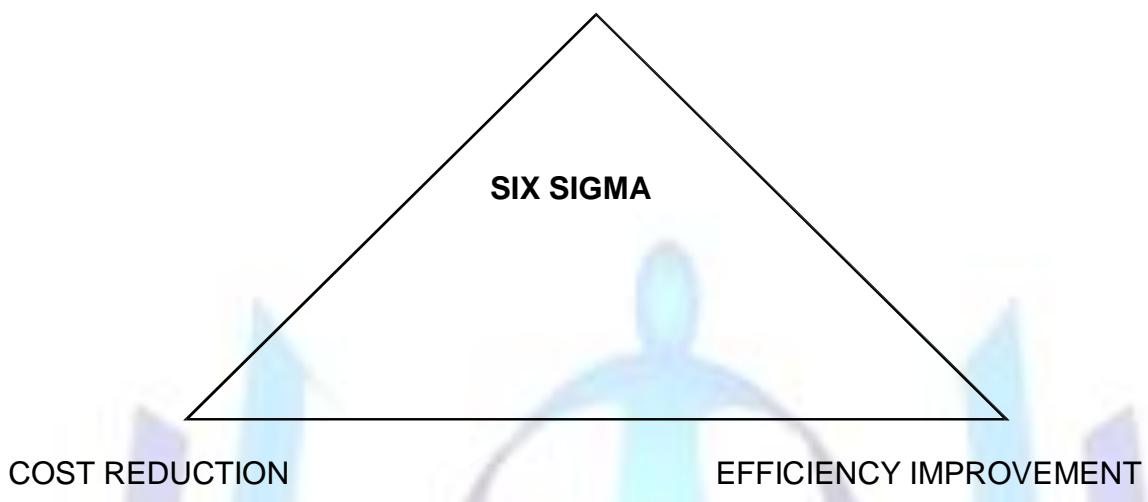

\section{Benefits of Six Sigma}

Since operating rooms (ORs) are resource-intense and costly hospital units. Maximizing OR efficiency is essential to maintaining an economically viable institution. Six Sigma methodologies were developed in the manufacturing industry to increase efficiency by eliminating non-value-added steps.

\section{"SIX SIGMA - CUSTOMER FOCUSED, PROJECT FOCUSED, RESULTS DRIVEN"}

Using such technique, this study deals to meet the needs of the patient undergoing surgical intervention. Within a safe environment, hospital has to provide a high standard of holistic care in a professional manner. Six Sigma is a problem solving methodology that improves any existing business process by constantly reviewing and re-tuning the process. To achieve this, Six Sigma uses a Methodology known as DMAIC.

\section{DEFINE PHASE}

The primary objectives of the define phase are:

- To identify the focus areas or key performance measures.

- To identify the improvement opportunity.

\section{SIPOC Diagram}

The following SIPOC diagram describes the OT process.

\begin{tabular}{|c|c|c|c|c|}
\hline SUPPLIER & INPUT & PROCESS & OUTPUT & CUSTOMER \\
\hline OT Nurse & $\begin{array}{l}\text { Respective } \\
\text { Wards }\end{array}$ & $\begin{array}{l}\text { Patient } \\
\text { wheeled in }\end{array}$ & $\begin{array}{l}\text { Wheeling into } \\
\text { the theatre }\end{array}$ & Anesthetist \\
\hline Anesthetist & $\begin{array}{l}\text { Anesthesia } \\
\text { equipment and drugs }\end{array}$ & $\begin{array}{l}\text { Induction of } \\
\text { Anesthesia }\end{array}$ & $\begin{array}{l}\text { Patient ready } \\
\text { for Incision }\end{array}$ & Surgeon \\
\hline Surgeon & $\begin{array}{l}\text { Instruments } \\
\text { and equipment }\end{array}$ & $\begin{array}{l}\text { Incision for } \\
\text { surgery }\end{array}$ & Surgery done & $\begin{array}{l}\text { Nurse in } \\
\text { charge }\end{array}$ \\
\hline Nurse In charge & $\begin{array}{l}\text { Monitoring } \\
\text { Patients Vitals }\end{array}$ & $\begin{array}{l}\text { Anesthetist } \\
\text { Check Patient condition }\end{array}$ & $\begin{array}{l}\text { Patient is out } \\
\text { of Anesthesia }\end{array}$ & OT technician \\
\hline OT Technician & $\begin{array}{l}\text { Trolley and } \\
\text { Stretcher }\end{array}$ & $\begin{array}{l}\text { Wheeling out } \\
\text { of patient }\end{array}$ & $\begin{array}{l}\text { Transfer to } \\
\text { Post OP }\end{array}$ & OT technician \\
\hline OT technician & $\begin{array}{l}\text { Trolley and } \\
\text { stretcher }\end{array}$ & $\begin{array}{l}\text { Preparing the } \\
\text { theatre for the next } \\
\text { case }\end{array}$ & $\begin{array}{l}\text { OT ready for } \\
\text { next case / } \\
\text { surgery }\end{array}$ & OT Nurse \\
\hline
\end{tabular}




\section{MEASURE PHASE}

The primary objectives of the measure phase are;

- To develop data collection plan and to collect data

- To define the relation between the process variation and process specification.

- To find the subgroups those are out of control.

- To identify the trend of surgeries performed during the period of study.

\section{DATA COLLECTION PLAN}

- Measurement Method - The starting and ending time of procedures was recorded using the data collection sheet as per Annexure A.

- Measurement System Analysis - The chances of repeatability error are avoided by using a standard data collection sheet by one operator/data collector.

- Sample Size - The patients who got admitted during the period of study has been taken in to account. Therefore the sample size is 228 .

\section{BASELINE PERFORMANCE}

\section{DPMO (Defects Per Million Opportunity) analysis}

The defect per million opportunities has been analyzed to find the present sigma level has been shown in the table.

\section{Defects per Million Opportunities Analysis}

\begin{tabular}{|c|c|c|c|}
\hline Number of defects & $\begin{array}{c}\text { Number of defect } \\
\text { opportunities }\end{array}$ & Number of units & Sigma level \\
\hline 180 & 5 & 2 & 2.6 \\
\hline
\end{tabular}

Source: primary data

\section{Operation Theatre Efficiency}

\begin{tabular}{|c|c|c|c|}
\hline Availability & $\begin{array}{c}\text { Number of } \\
\text { scheduled cases }\end{array}$ & $\begin{array}{c}\text { Success rate of } \\
\text { surgeries }\end{array}$ & $\begin{array}{c}\text { Efficiency rate } \\
\sum \text { (percent) }\end{array}$ \\
\hline 6 & 4.36 & 4.36 & 54.5 \\
\hline
\end{tabular}

Source: primary data

\section{Process Capability- Cp}

\begin{tabular}{|l|c|}
\hline \multicolumn{1}{|c|}{ PARAMETERS } & VALUE \\
\hline LSL & 15 \\
\hline USL & 360 \\
\hline SAMPLE MEAN & 72.21 \\
\hline SAMPLE SIZE & 228 \\
\hline STANDARD DEVIATION (within) & 50.21 \\
\hline STANDARD DEVIATION (overall) & 50.15 \\
\hline CP & 1.15 \\
\hline
\end{tabular}

\section{ANALYSIS PHASE}

The primary objectives of the analysis phase are:

- To analyze all possible causes

- To shortlist major suspected causes (vital few)

- To verify root causes 
- To find the failure modes and potential causes

\section{CAUSE AND EFFECT DIAGRAM}

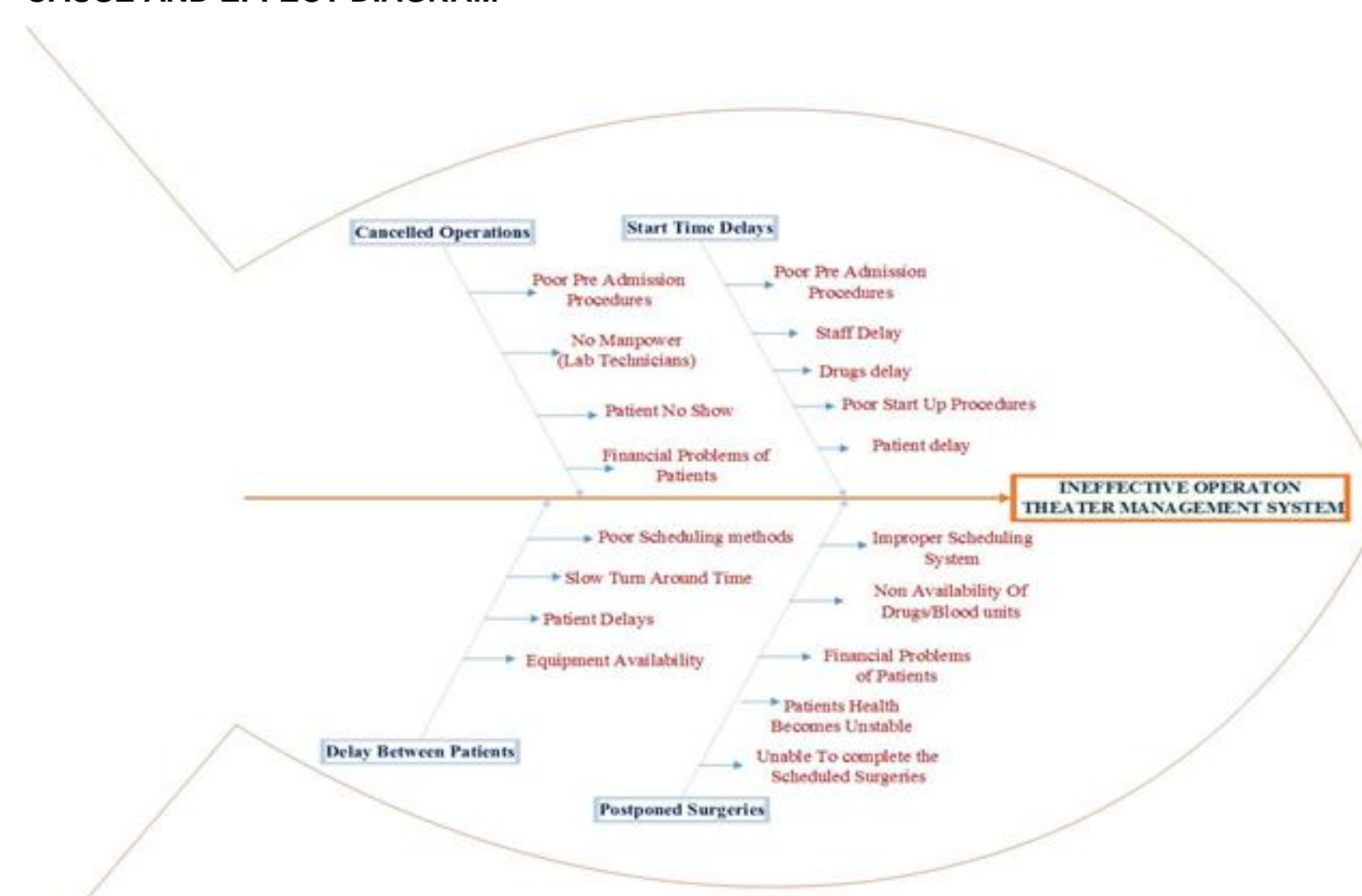

\section{IMPROVE PHASE}

The primary objectives of the improvement phase are

- To identify and evaluate possible improvement solutions

- To confirm possible improvement solutions towards optimized performance.

The Researcher attended surgeries to inspect the time taken for safety practices, and the use of the white board to record extra items, time, double counting of instruments, etc.

The Researcher handled documentation and data management, and revised the nursing forms, integrated essential fields on safety and the fields required as per standard requirements. A nursing record form was piloted and nurses' recommendations were integrated, the nursing educators were involved ensuring that guidelines on how to fill the form were communicated to the nurses.

A module has been developed and suggested to the organization has mentioned above.

\section{POSSIBLE IMPROVEMENT SOLUTIONS}

The sigma level can be increased up to six levels, which helps in forming an effective and efficient operation theatre.

- The efficiency rate can be improved to 90 percent -100 percent to make the Operation theatre more productive.

- Operating theatre / reservation schedule table shall be arranged and shall be posted in the room of Anesthesia Head and Chief Matron.

- The following details can be furnished in the Operation Theatre Schedule table;

- Patient details

- Hospital number

- Schedule time

- Operation (Name) 
- Start Time

- End Time

- Surgeon

- Anesthesia

- Type of Anesthesia

- Staff Initials

- Remarks

* Remarks column shall be noted down using codes which helps to identify the unutilized Operation Rooms and can be made better utilized

\section{Codes for Cancelled Surgeries}

C1- Unavailable

C2-Patient refuse / No Show

C3- Insurance /Financial Problem

C4-Medical Problem

C5- Doctor Unavailable

\section{Codes for Postponed Surgeries}

Po- No Specific Reason / No definite dates

P1-Non Availability of Operation room

P2-Non Availability of Blood

P3- Insurance /Financial problems

P4-Medical related problems

P5-Non Availability of Doctors

\section{Codes for Delayed Surgeries}

D1- Non Availability of Operating rooms

D2- Non Availability of Blood and delay in Lab tests

D3-Unstable condition of Patient

D4-Delay in wheeling in the patient from the ward/ ICU and so on

D5-Delay in arrival of Doctors to the Operation Theatre

- These details can also be linked in to the Hospital Information System for the ease of storing, searching and retrieval of Patient details.

- Check list forms shall be used to monitor the Operation Theatre Stock replacements, in order to eliminate the Out of Stock issues.

- The check lists shall be more focused to the following areas like;
- Recovery Room
- Anesthesia Trolley
- Biomedical Equipment and Spares

Daily Consumables Charge list shall be maintained, to avoid the lack in supply during the procedure

Preference Cards shall be implemented to avoid the failure during the preparation of surgeries, this preference cards shall have the following areas

- Supplementary Instruments

- Catheters

- Drains

- Equipment

- Gloves 
- Medications

- $\quad$ Sutures

- Blades

- Lenin

- Consumables/Supplies

- Prosthesis -Implants and so on

- Environmental Checklists shall be maintained appropriately to reduce the risk of Infection.

- Operation Theatre Nurses Manual shall be formulated and distributed to the Matron Office which could help in both Documentation and Daily check.

- The Proper manual gives the better understanding for the Operation Theatre flow. The manual shal include the following details

- Pre-Operative Records

- Intra Operative Records

- Post-Operative Records

- The Assessment record shall be maintained along with the Manual which will help in getting a clear view on the Operation Theatre flow.

- The method of filling the above said manual shall be communicated to the nurses.

- A Proper Biomedical Team Shall be formed and used to maintain the complete documentation including

- Date of Inspection/ Intervention

- Identification Of the Inspected equipment(S.No, Asset No. and so on)

- The Type of Inspection Completed

- The Results of the Inspection

- Name and Designation of the Person who completed the inspection

- Any replacements/ repairs of Spares

- The Biomedical Team shall conduct audit at regular intervals to avoid breakdown of equipment.

- To avoid start time delay the use of the above stated Operation Theatre Scheduling table shall be implemented

- Lab Technicians can collect the samples of patients from the respective wards and the results can be made available to the Operation theatre with the help of a Hospital Information System or it can be directly delivered to the OT with the help of lab Assistants.

- A separate OT pharmacy shall be introduced inside the OT complex which would prevent the delay caused in receiving medicines and drugs during the surgeries.

- Another Scrub Area can be introduced which can save the time taken by surgeons and other medical professionals during the Intra Operative Procedures.

- It has been suggested to the HR department to recruit more OT staffs under the cadre of technicians to avoid delays caused in the Preparation of OT rooms before surgeries.

- An Operation Theatre Management system shall be implemented which can be a substitute for the Nominal register to minimize paper works and also reduce errors.

- It has been suggested to the matron chief to make use of the OT cleaning procedures based on NABH standards, in which a check list shall be prepared for the successful follow up.

- A continuous monitoring shall be conducted by the anesthesia head on the above mentioned factors.

\section{CONTROL PHASE}

\section{The primary objectives of the control phase are:}

- To standardize improvement plan to sustain the gains of the improvement

- To give suggestions to close the improvement project

\section{RECOMMENDATIONS}

- The suggested module has to be implemented and further observation and measurement has to be done to identify the increased sigma level after implementation, which gives the scope for further research.

- It is also proposed that the post implementation performance shall be measured to evaluate and sustain the improved performance. 
- The project report was submitted to the management and the management is considering the implementation.

\section{REFERENCES}

[1] Calms, S.H. \& Shusterich, K.M. 1992. Operating room management: what goes wrong and how to fix it. Physician Executives, Nov-Dec

[2] Christian, C. K. (2006). A prospective study of patient safety in the operating room. Surgery, 139: 159-173.

[3] Dexter, F. \& Traub, R.D. 2002. How to schedule elective surgical cases into specific operating rooms to maximize the efficiency of use of operating room time. Anesth Analg, 94: 933-942.

[4] Park, K.W. \& Dickerson, C. 2009. Can efficient supply management in the operating room save millions? Current opinion Anaesthesiology, 22: 242-248

[5] Baulcomb, J.S., 2003. Management of change through focused force field analysis. Journal of Nursing Management, 11:275-280.

[6] Butler, M., Boxer, E. \& Sutherland-Fraser, S. 2003. The factors that contribute to count and documentation errors in counting. ACORN Journal, 16(1): 10-14.

[7] HSE. 2009 improving our services: a user's guide to managing change in the health service executives. Dublin.

\section{Author' biography with Photo}

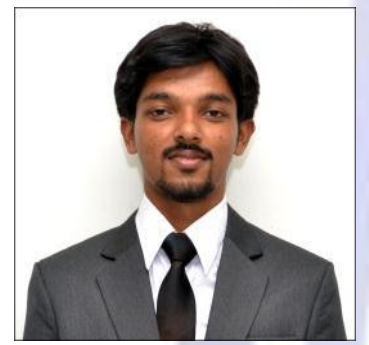

Name: Vishnu V Raja, B.E Biomedical Engineering, MBA Hospital \& Health Systems Management

DOB: 19/11/1989

Mobile Number: 9789886822

Email Id: vishubme@gmail.com

2012 - Won $1^{\text {st }}$ Place in Ad-Zap at "QUEST'12", A National Level Management Meet held at SRM University.

2010 -The major project titled 'Non Invasive Measurement of Biological Parameters for

Continuous Patient

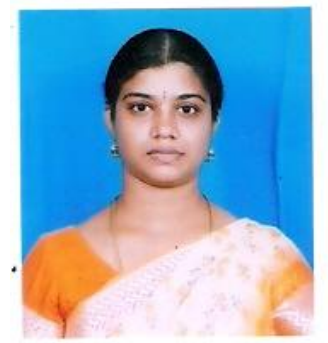

Mrs. BHOOMA DEVI, B.Sc., MHM, SSBB, Ph.D

Experience: 8 years

Designation: Senior Lecturer, Sri Ramachandra College of Management, Sri Ramachandra University, Porur, Chennai - 116

Certified SIX SIGMA GREEN BELT and SIX SIGMA BLACK BELT

Area of Specialization: Hospital Management, Total Quality Management in Hospitals, HR Mobile -9884022001

E mail- bhooma.ganesh@gmail.com

NEN certified faculty

Five publications in national and international journals. 